AGRARIS: Journal of Agribusiness and Rural Development Research

Vol. 6 No. 2 July-December 2020

Article history:

Submitted : November $16^{\text {th }}, 2019$

Accepted : November $3^{\text {rd }}, 2020$
Muhammad Joni Iskandar*, Jamhari

Universitas Gadjah Mada, Indonesia

*) Correspondence email: joniiskandar1508@gmail.com

\title{
Efficiency of Rice Farming in the Corporate Farming Model in Central Java
}

DOI: https://doi.org/10.18196/agr.6297

\begin{abstract}
The corporate farming approach on rice is aimed to increase the production on fields with the constraints of limited land area. The present research was aimed to analyze the impact of the implementation of corporate farming on the production, efficiency and inefficiency of the law land farming. The study was determined purposively in farmers' group union "Tani Mandiri Dalangan” in Sukoharjo Regency, Central Java. Sampling of the respondents used a census method involving all members totaling 51 farmers over two growing seasons. Data were analyzed using the frontier stochastic production function Maximum Likelihood Estimation (MLE) method frontier computing program 4.1c. The results showed that the corporate farming of rice production was affected by land area, Urea fertilizer and NPK fertilizer. Technical, economical and allocative efficiency corporate farming of rice farming has not been efficient. Technical efficiency shows the lowest efficiency value due to the use of factors of production exceeding the recommended regional dosage. Socio-economic factors that significantly affected the technical inefficiency of the low land rice farming are education, family size and extension.
\end{abstract}

Keywords: Corporate Farming, Efficiency, Inefficiency, Production

\section{INTRODUCTION}

Agricultural land is the type of land that has been converted the most, especially paddy fields. Land conversion to industrial, service, property and residential sectors causes a transformation of the structure of agricultural land tenure. This is because the opportunity to increase land area is very limited and the proportion of farmers' land ownership is getting narrower (Susilowati \& Maulana, 2016). The average land ownership for farmers nationally is less than 0.5 ha (Subejo, 2018). The scale of land tenure is low and tends to be unstable, which affects the ability of farmers to produce. Therefore, farming profits are relatively small. Even if there is an increase, the profits obtained will show a meaningless increase due to high production costs (Suharyanto, Mulyo, Darwanto, \&Widodo, 2015).

Land availability as agricultural input is an absolute prerequisite for realizing a sustainable agricultural sector. Land plays an important role in line with regional development, population growth, and economy, while land area is fixed in nature, in the sense 
that the total land resources of an area are fixed (Zakaria \& Rachman, 2013). The scarcity of land resources is not only a limited supply but also fragmentation that is difficult to avoid due to the system of inheritance culture that develops among farmers. Land fragmentation is an obstacle to agricultural development (Asiama, Bennett, \& Zevenbergen, 2017). Modernization and mechanization of agriculture are difficult to do on narrow and separate lands (Liu et al., 2019). In addition, fragmentation causes a decrease in the production of productive land so that the costs sacrificed by farmers to achieve potential production are high (Munnangi, Lohani, \& Misra, 2020).

Efforts to control land-use change and fragmentation can be carried out by implementing corporate farming. Corporate farming is an amalgamation of paddy fields to be managed jointly under the auspices of one managerial (Musthofa \& Kurnia, 2018). In this case, the farmer becomes a shareholder in accordance with the area of land they own so that the distribution of results is based on land area. Meanwhile, individual agriculture is managed personally. Thus, intensification through corporate farming is a strategic step because increasing production through extensification is not possible, especially the high fragmentation and conversion of land to non-agricultural functions. In addition, farming costs can be minimized by mechanization, although agricultural labor is still available, in limited numbers (scarce) and the wages are quite high, while farmers are faced with limited capital. The corporate farming model is more efficient than traditional farming (Kostov, Davidova, \& Bailey (2019). However, the implementation of corporate farming raises various new problems, including farmers who apply their land, as a corporate will lose their jobs because they do not have other alternative jobs that provide better welfare. The existence of sociocultural differences causes some farmers not to fully entrust their land to be managed as a corporate and the distribution of results is not appropriate because the profit- sharing is determined based on a land area without considering land fertility (Musthofa \& Kurnia, 2018).

The center for low land rice development as well as the implementation of corporate farming is located in Sukoharjo Regency. The rate of increase in production and productivity of low land rice in Sukoharjo Regency during the period 2010 to 2016 fluctuated with an average production of 314,753 tons/ha and productivity of $65.46 \mathrm{~kW} / \mathrm{ha}$ (BPS, 2018). The highest increase in production in 2016 was 391,675 tons/ha, but productivity tended to decrease by $-3.18 \mathrm{~kW} /$ ha or $-0.62 \%$. Slowing productivity is partly due to inefficient managerial use of production factors. Even though the use of inputs is the key to the success of rice farming (Yuliana, Ekowati, \& Handayani, 2017). Therefore, improving production through efficiency is the right choice. Through efficiency, farmers can determine the number and combination of production factors used to produce farming efficiency.

Previous efficiency research has focused more on the aspects of individual agriculture that are managed independently. Among those researches are the estimation of the efficiency of rice farming in Central Java using frontier analysis (Darwanto, 2010), analysis of the efficiency of rice farming in several rice production centers in Indonesia using the stochastic frontier estimation (Kusnadi, Tinaprilla, Susilowati, \& Purwoto, 2011), technical efficiency 
research , economic and allocative rice farming in Central Lampung Regency, the estimation of the Cobb-Douglas stochastic frontier production function using direct farm input variables (Yoko, Syaukat, \&Fariyanti, 2014), analysis of efficiency and income of rice farming in SengahTemila District, Landak Regency using the stochastic production function frontier analysis (SFA) (Pudaka \& Prasetyo, 2018), research on production analysis and efficiency of integrated rice crop management in Bali Province by comparing the application of the SL-PTT system using the stochastic function production maximum likelihood estimation (MLE) (Suharyanto, Mulyo, Darwanto, \& Widodo, 2015).

Meanwhile, the literature on the efficiency of the corporate farming model of rice farming is still rare. Therefore, research on the efficiency of rice farming in the corporate farming model needs to be done. This study aims to estimate the efficiency of rice farming using the corporate farming model in Sukoharjo Regency technically, economically, and allocatively. The application of rice farming with the corporate farming model tends to make farmers more careful in managerial use of production factors to achieve minimum cost efficiency, especially in the use of labor input which until now has experienced scarcity, and ultimately the labor wage is getting higher in production. It is hoped that the results of this research can be used by farmers as a consideration for the sustainability of agriculture in the corporate farming model as an anticipation model for land-use change and increasingly massive fragmentation.

\section{RESEARCH METHOD}

The research location was determined purposively, namely Sukoharjo Regency, Central Java, with the consideration that it is a center for low land rice production as well as a national food barn that implements corporate farming in 2017. The sample is limited to members of farmers' group union "Tani Mandiri Dalangan”. The samples were taken using a census technique for each farmer group in this farmers' group union, including 7 farmers for the "Ngudi Rahayu" Farmer Group, 16 farmers for the "Asri Rata" Farmer Group, 13 farmers for the "Ngudi Rejeki" Farmer Group, and 15 farmers for the "Ngudi Mulyo" Farmer Group. The total sample as a whole is 51 samples of farmers. The data structure for measuring production factors and efficiency includes low land rice farming input-outputs collected for two growing seasons in order to obtain inter-season variation in production. Data were collected through structured interviews with all members of corporate farming.

The data is estimated using the stochastic production function frontier, computation program frontier 4.1c. This model is used based on the consideration that corporate farming farmers have reached their limit of production (frontier) so that on the same land, production can still be increased by using proportional input and existing technology. Production function parameters estimation, technical efficiency, and source of inefficiency are estimated simultaneously by using the technical efficiency effects model with the Maximum Likelihood Estimation (MLE) method. In addition, the source of inefficiency can be estimated whether the dominant term error occurs due to inefficiency $(\mu \mathrm{i})$ or noise (vi) such as weather, pests and 
diseases, natural disasters, and so on. Furthermore, economic and allocative efficiency is estimated by deriving the dual cost function from the production function.

The empirical model of the Cobb-Douglass frontier stochastic production function which was used to estimate the production function includes rice production $(\operatorname{Ln~} \mathrm{Y})(\mathrm{kg})$, intercept $(\beta 0)$, estimator parameters $(\beta 1-\beta 6)$, random/noise variables (vi), technical inefficiency effects. $(\mu \mathrm{i})$, and X1-X6 are the quantity of conventional input from farming which consists of land area (ha), Urea fertilizer $(\mathrm{kg})$, SP-36 fertilizer $(\mathrm{kg})$, NPK fertilizer $(\mathrm{kg})$, pesticides (liters), and labor. (HOK). The model can be written as follows.

$\operatorname{Ln} Y=\beta 0+\beta 1 \ln X 1+\beta 2 \ln X 2+\beta 3 \ln X 3 .+\beta 4 \ln X 4+\beta 5 \ln X 5+\beta 6 \ln X 6+(v i-$

ui)

The expected value of all estimating parameters $\beta 1-\beta 6>0$ is positive, which means that additional use of production factors can increase rice production.

The technical efficiency of corporate farming is analyzed through the ratio of actual production $(\mathrm{Yi})$ to potential production $\left(\mathrm{Yi}^{\wedge^{\wedge}}\right)$ as follows (Jondrow, Lovell, Materov, \& Schmidt, 1982).

$\mathrm{TE}_{\mathrm{i}}=\frac{\mathrm{Yi}}{\mathrm{Yi}^{*}}=\frac{\mathrm{E}(\mathrm{Yi} \mid \mathrm{Ui}, \mathrm{Xi})}{\mathrm{E}(\mathrm{Yi} \mid \mathrm{Ui}=0, \mathrm{Xi})}=\left[\exp \left(-\mu_{\mathrm{i}}\right)\right]$

TEi is the technical efficiency of the $\mathrm{i}$-th farmer, exp $(-\mu \mathrm{i})$ is the expected value of technical efficiency, namely $(0<\mathrm{Tei}<1)$. Meanwhile, to determine the value of the distribution parameter $(\mu \mathrm{i})$, it is assumed that it is free and normally truncated with $N\left(\mu \mathrm{i} \sigma^{\wedge} 2\right)$. The effect of technical inefficiency in this study uses the following equation.

Economic efficiency is analyzed by reducing the stochastic frontier cost function including rice production costs (C) (IDR), estimating parameters ( $\beta 1-\beta 6)$, random/noise variables (vi), technical inefficiency effects $(\mu \mathrm{i})$ and P1-P2 is the price of farm input. Including rice production $(\mathrm{kg})$, urea fertilizer price $(\mathrm{IDR} / \mathrm{kg})$, SP-36 fertilizer price (IDR/ $\mathrm{kg}$ ), NPK fertilizer price (IDR/kg), pesticide price (IDR/lt) and labor wage-price (IDR/HOK). The equation for the corporate farming cost function of rice is as follows.

$\operatorname{Ln} C=\beta 0+\beta 1 \ln \mathrm{P} 1+\beta 2 \ln \mathrm{P} 2+\beta 3 \ln \mathrm{P} 3+\beta 4 \ln \mathrm{P} 4+\beta 5 \ln \mathrm{P} 5+\beta 6 \ln \mathrm{P} 6+(\mathrm{vi}-\mu \mathrm{i})$

According to Jondrow, Lovell, Materov, \& Schmidt (1982) economic efficiency is determined by the ratio of the minimum observed total cost of production $\left(\mathrm{C}^{*}\right)$ to the total actual total cost of production $(\mathrm{C})$ as in the following equation.

$\mathrm{EE}=\frac{C^{*}}{C}=\frac{\mathrm{E}(\mathrm{Ci} \mid \mathrm{Ui}=0, \mathrm{Yi}, \mathrm{Pi})}{\mathrm{E}(\mathrm{Yi} \mid \mathrm{Ui}, \mathrm{Yi}, \mathrm{Pi})}=\mathrm{E}\left[\exp \left(-\mathrm{U}_{\mathrm{i}} \mid \varepsilon\right)\right]$

By using the 4.1c frontier computation program, the cost efficiency value is obtained. Therefore, the economic efficiency of corporate farming is obtained using the following equation.

$\mathrm{EE}=\frac{1}{\text { Cost Efficiency (CE) }}$

Economic efficiency is a combination of technical and allocative efficiency so that allocative efficiency (EA) can be obtained by the following equation. 
$\mathrm{EA}=\frac{\text { Efisiensi Ekonomi (EE) }}{\text { Efisiensi Teknis (TE) }}$

\section{RESULT AND DISCUSSIONS}

Recently, corporate farming has not been fully implemented. Farming activities carried out as a corporate are limited to land production factors, seeding, planting, and harvesting, while maintenance is left to each farmer. Therefore, the use of input quantities of fertilizer, selection of seeds, and pesticides is in accordance with what the farmers expect. All activities using mechanization become corporate activities, the rest that does not use mechanization become individual non-corporate activities. Thus, the focus of implementing the corporate farming model is on the efficient use of agricultural tools and machinery in reducing the use of the number of workers so that cost efficiency is achieved in addition to the increasingly limited availability of labor.

The corporate farming model of rice farming activities begins with the merging of land simultaneously to eliminate land boundaries in order to facilitate mechanization. The land boundaries were previously marked with stakes as the boundaries of land ownership. Land processing uses a four-wheeled tractor. Seedlings use grain seeders with a tray or dapog. Cultivation is carried out twice as often as the growing season in one year. This means that farmers plant rice continuously for two seasons without rotation. Planting was carried out simultaneously using a rice transplanter. The spacing is set directly at the time of planting 30 $\mathrm{cm}$ x $15 \mathrm{~cm}$. Harvest uses a combine harvester.

\section{Allocation of Use of Production Factors}

The production factors used in the study were land area, urea fertilizer, SP-36 fertilizer, NPK fertilizer, pesticides, and labor. Production factors carried out in a corporate manner include land and labor. The average allocation for the use of production factors can be seen in Table 1. The average land area for corporate farming farmers in Sukoharjo Regency is 0.42 ha and is classified as still narrow. In line with the opinion of Susilowati \& Maulana (2016), the average agricultural land ownership ranges from 0.1 to 0.4 ha per farmer household.

The majority of farmers in the corporate farming use three types of macro fertilizers, namely Urea fertilizer, SP-36 fertilizer, and NPK fertilizer. The average use of Urea fertilizer is 263.01 (kg/ha), SP-36 fertilizer 233.73 (kg/ha) and NPK fertilizer 322.30 (kg/ha). The amount of fertilizer used has exceeded the recommended location-specific dosage. The recommended dosage for fertilizer in Sukoharjo Regency is Urea 250 (kg/ha), SP-36 75 (kg/ha) while NPK 50 ( $\mathrm{kg} / \mathrm{ha}$ ) (Apriyantono, 2007). The habit of using fertilizers in large quantities is generally influenced by farmers' perceptions; the use of more production factors gives the possibility of high production. Even though rice plants absorb nutrients as needed, excessive provision results in the soil which becomes acidic, the ability to absorb nutrients is inhibited and the cost of farming is higher (Riyadi, Hartono, \& Andri, 2015).

The use of pesticides by farmers varies, the average use of pesticides is 2.5 liters/ha. Pest attacks that often occur in corporate farming include stem borer, stinkbug, brown plant 
hopper, rats, and birds. Spraying is carried out 3-5 times per growing season according to the attack and variety of pests and diseases. The more intensity of spraying, of course, harms plants and the environment. Even though the use of active ingredients is low, exceeding the threshold can harm farmers because they threaten the existence of natural enemies which leads to the existence of more pest attacks (Yuliana, Ekowati, \& Handayani, 2017). The average use of the corporate farming labor force in Sukoharjo Regency as a whole is 14.81 HOK. The labor production factor that becomes the research variable is labor that is not together so that the use of the number of workers is relatively smaller. The allocation of the use of labor in the family of $2.73 \mathrm{HOK}$ or $19 \%$ is used in semi-corporate farming activities while the remaining $81 \%$ of the workforce is outside the family activities together.

TABLE 1.ALLOCATION OF THE USE OF RICE PRODUCTION FACTORS FOR CORPORATE FARMING IN SUKOHARJO REGENCY 2018-2019

\begin{tabular}{lcr}
\hline Production Factors & Unit & Average \\
\hline Land area & $\mathrm{Ha}$ & 0.42 \\
Urea fertilizer & $\mathrm{Kg}$ & 263.01 \\
SP-36 fertilizer & $\mathrm{Kg}$ & 233.73 \\
NPK fertilizer & $\mathrm{Kg}$ & 322.30 \\
Pesticide & Liter & 2.5 \\
Labor & HOK & 14.81 \\
\hline
\end{tabular}

Source: Primary Data Analysis

\section{Factors that Affected Rice Production}

The results of data processing using the 4.1c frontier program provide estimates of regression parameters using the Maximum Likelihood Estimation (MLE) method presented in Table 2 . The sigma-squared value $\left(\sigma^{\wedge} 2\right)$ of 0.0020 is significant at the $\alpha$ level of $1 \%$. This means that the error term is normally distributed. The gamma $(\gamma)$ value of 0.9999 tratio value of 20.763 shows that $99.99 \%$ of the residual variation in the model is more dominant due to technical inefficiency $(\mu \mathrm{i})$ the remaining $0.01 \%$ is due to noise (vi) such as weather, climate, pests and diseases, natural disasters, etc. If all error terms are caused by noise (vi), the parameter value of the inefficiency coefficient becomes meaningless (Kusnadi, Tinaprilla, Susilowati, \& Purwoto, 2011). The value of the log-likelihood function MLE $(39,123)$ is greater than the log-likelihood function OLS $(34,090)$. Therefore, the model used is good enough to describe the actual conditions of corporate farming.

Measurement of production factors and efficiency uses semi-corporate variables to obtain measurement variations in the model. It is suspected that the production variables including land area, urea fertilizer, SP-36 fertilizer, NPK fertilizer, pesticides, and labor have a significant effect on rice production. Table 2 shows that the variables of land area, urea, and NPK fertilizer have a significant effect on rice production. The elasticity of production of the frontier area of land, urea, and NPK fertilizers were $1.1370,-0.1765$, and -0.1346 , respectively. The variable of the land area is the most elastic among other variables, meaning that the increase in farm area can increase the production which is greater than the variables of urea and NPK fertilizers.

The average land area of 0.42 ha has a significant effect on rice production. The coefficient of land area production factor is positive according to the expected sign of 0.9486 , 
which means that every $1 \%$ increase in a land area increases rice production by $0.9486 \%$. In line with the findings of Kusnadi, Tinaprilla, Susilowati, \& Purwoto (2011); Akbar, Budiraharjo \& Mukson (2017); and Suharyanto, Mulyo, Darwanto, \& Widodo (2015), the variable land area is the variable that has the most significant effect on increasing rice production. The positive influence of land on production was also revealed by Defidelwina, Jamhari, Waluyati, \& Widodo (2019), where the most elastic land area increases rice production. The wider the cultivated land, the greater the average rice production. The area of land for farmers to achieve welfare is at least 0.65 ha (Susilowati \& Maulana, 2016). However, the facts in the field show that the average land ownership for corporate farming farmers is 0.42 ha, meaning that there is still a difference of 0.23 ha from the minimum limit. One of the reasons for the size and structure of farmers' land tenure that is not yet conducive is the implementation that has not been fully implemented in a corporate manner.

\begin{tabular}{|c|c|c|c|c|}
\hline Variable & Expectation Value & Coefficient & Std.Error & t-ratio \\
\hline Constant & $+/-$ & 0.2992 & 0.6678 & 0.4480 \\
\hline In land area & + & $1.1370^{* * *}$ & 0.1204 & 9.4404 \\
\hline Ln Urea fertilizer & + & $-0.1765^{* *}$ & 0.0705 & -2.5010 \\
\hline Ln SP-36 fertilizer & + & -0.0379 & 0.0387 & -0.9779 \\
\hline Ln NPK fertilizer & + & $-0.1346^{* *}$ & 0.0610 & -2.2069 \\
\hline Ln pesticide & + & 0.0135 & 0.0316 & 0.4271 \\
\hline Ln labor & + & 0.0140 & 0.0440 & 0.3193 \\
\hline Sigma-squared & & 0.0020 & 0.0031 & 6.3909 \\
\hline Gamma & & 0.9999 & 0.0000 & 41.853 \\
\hline Log likelihood function OLS & & 34.090 & & \\
\hline Log likelihood function MLE & & 39.123 & & \\
\hline LR test of the one-sided error & & 10.066 & & \\
\hline
\end{tabular}

Source: Primary Data Analysis

${ }^{* * *}$ : significant at the $1 \%$ level, $\mathrm{t}$-table $1 \%=2.6799$

${ }^{* *}$ : significant at the $5 \%$ level, $t$-table $5 \%=2.0095$

Urea fertilizer has a significant effect on rice production, but it is against the expected signs. The coefficient value of urea fertilizer production factor is -0.1878 . This figure means that with the addition of $1 \%$ urea fertilizer, rice production decreased $0.1878 \%$. Urea fertilizer which reduces production is not in line with the research of Yoko, Syaukat, \& Fariyanti (2014); the addition of Urea fertilizer can still increase low land rice production even though the increase is low. Rice plants need nutrients in dynamic equilibrium conditions, meaning that if these nutrients are still deficient or in excess, they affect the increase in yield levels. This follows the law of diminishing marginal return, increasing the amount of input to a certain limit can reduce low land rice production. On the other hand, the use of insufficient inputs is a constraint on production (Riyadi, Hartono, \& Andri, 2015).

The NPK fertilizer variable has a significant effect on rice production at an $\alpha$ level of $10 \%$. The regression coefficient of the NPK fertilizer variable was -0.1254 , meaning that with the addition of $1 \%$ NPK fertilizer, rice production decreased by $0.1254 \%$. This result is 
contrary to the findings of Yuliana, Ekowati, \& Handayani (2017), which states that the use of NPK fertilizer (phonska) has a positive effect on production, which means that the addition of NPK fertilizer can still increase rice production. The average use of NPK fertilizer for corporate farming farmers is $322.30 \mathrm{~kg} / \mathrm{ha}$. This amount exceeds the recommended dosage for areas where NPK fertilizer according to the principle of balanced fertilization is $50 \mathrm{~kg} / \mathrm{ha}$ (Apriyantono, 2007). The farmers' habit of using macro fertilizers massively per planting season has resulted in high soil residues while the previous fertilization nutrients have not broken down completely. The use of chemical fertilizers without being followed by rehabilitation might create the possible risk such as the degradation of agricultural land, and ultimately this causes a decrease in production (Riyadi, Hartono, \& Andri, 2015).

\section{Technical, Economic, and Allocative Efficiency}

Research on the corporate farming model previously described by Lerman \& Sedik (2007) uses three input models (land and labor), input (land, labor, and number of agricultural machinery) and inputs (land, labor, number of agricultural machines and nurseries), agriculture. The corporate model is more efficient than non-corporate agriculture with the efficiency value of the corporate model agriculture $(>0.70)$ while the non-corporate agriculture $(<0.70)$. This result is not in line with the findings of Kostov, Davidova, \& Bailey (2019), using non-corporate agricultural labor input more efficiently than corporate model agriculture in several countries such as Romania, Spain, Hungary, and the Czech Republic. Furthermore, Kostov, Davidova, \& Bailey (2019) stated that traditional agriculture is the foundation of the family economy (subsistence) so that they are more serious in achieving their efficiency. This efficiency can be increased by increasing farm managerial abilities (Kostov, Davidova, \& Bailey, 2019). Meanwhile, the corporate farming model in Sukoharjo Regency based on stochastic frontier analysis is not technically, economically, and allocatively efficient. This result is in line with the findings of Kostov, Davidova, \& Bailey (2019) where the corporate model of agriculture is not yet fully efficient.

TABLE 3. DISTRIBUTION OF TECHNICAL, ECONOMIC AND ALLOCATIVE EFFICIENCY VALUES OF CORPORATE FARMING IN SUKOHARJO REGENCY 2018-2019

\begin{tabular}{|c|c|c|c|c|c|c|}
\hline \multirow[t]{2}{*}{ Efficiency } & \multicolumn{2}{|c|}{ Technical } & \multicolumn{2}{|c|}{ Economic } & \multicolumn{2}{|c|}{ Allocative } \\
\hline & Number & $\%$ & Number & $\%$ & Number & $\%$ \\
\hline $0,50 \leq \mathrm{E}<0,60$ & 4 & 0.00 & 2 & 3.92 & 0 & 0 \\
\hline $0,60 \leq E<0,70$ & 4 & 1.96 & 3 & 5.88 & 0 & 0 \\
\hline $0,70 \leq E<0,80$ & 9 & 17.65 & 11 & 21.57 & 0 & 0 \\
\hline $0,80 \leq E<0,90$ & 13 & 25.49 & 16 & 31.37 & 4 & 7.84 \\
\hline $0,90 \leq E<1,00$ & 28 & 54.90 & 19 & 37.25 & 6 & 11.76 \\
\hline$>1,00$ & 0 & 0 & 0 & 0 & 41 & 80.40 \\
\hline Total & 51 & 100.00 & 51 & 100.00 & 51 & 100.00 \\
\hline Minimum & 0.56 & & 0.55 & & 0.80 & \\
\hline Maximum & 0.99 & & 0.99 & & 1.65 & \\
\hline Average & 0.75 & & 0.84 & & 1.12 & \\
\hline
\end{tabular}

Source: Primary Data Analysis

On average, farmers of the corporate farming achieve a technical efficiency of 0.75 from their frontier with the best management system (the best practice). The higher the 
efficiency value, the more increasingly difficult the opportunity to increase production (Yoko, Syaukat, \& Fariyanti, 2014). Corporate rice farming still has the opportunity to increase production by $15 \%$ from the frontier by optimizing the use of production factors, while others still require technological innovation and farm managerial improvements (Kostov, Davidova, \& Bailey, 2019).

Economic efficiency is estimated from the input and output side of the production at the average price at the farmer level. The price of each input and output includes the average price of dry unhulled rice which was 4,017.65 (IDR/ $\mathrm{kg})$. The average price of urea fertilizer was $1,901($ IDR $/ \mathrm{kg})$. The average price of SP-36 fertilizer was 2,309 (IDR/kg). The average price of NPK fertilizer was 2,464 (IDR/ kg). The average price of pesticides was 274,034 (IDR/lt) and the average labor price was 59,226 (IDR/HOK). The average economic efficiency of corporate rice farming is $\mathbf{0 . 8 4}$. If the average farmer can achieve the highest degree of economic efficiency, it can provide costs of 1 - $(0.84 / 0.99)$ or $15 \%$. Ineffective farmers can charge $1-(0.55 / 0.99)$ or $45 \%$. Meanwhile, the average allocative efficiency of rice farming in the agricultural companies of the Sukoharjo Regency is 1.12. If the average farmer can achieve allocative efficiency, it can guarantee costs 32\% 1-(1.12/1.65), while the least efficient farmers can provide costs $52 \% 1-(0.80 / 1.65)$.

It is indicated by field conditions that farmers of the corporate farming are not yet cost-oriented. This is indicated by the excessive use of production factors. Cost efficiency has not been achieved. When viewed from the structure of the cost of rice farming, the expenditure for mechanization reaches $57 \%$ and the remaining $43 \%$ is the expenditure on fertilizer production factors (Urea, SP-36, and NPK), seeds, and pesticides. Land processing by using a four-wheeled tractor is carried out after the land boundaries are leveled. The cost of cultivating by using a four-wheeled tractor is 875,585 (IDR/ha). The average cost ranges for seeding using a grain seeder of 1,000,000 (IDR/ha). Sowing seeds using a grain seeder aims to obtain uniform seeds to facilitate planting using a rice transplanter. Planting seeds by using a rice transplanter is done after the seedlings are not less than 14 days old, and planting them simultaneously in order to anticipate the attack of plant pests that cannot be predicted. The average land area of 0.42 ha requires at least 100 seed trays. The cost of planting with individual farmers' rice transplanters was 1,497,326 (IDR/ha), and harvesting using a combine harvester cost 1,996,435 (IDR/ha).

One-sample t-test was used to determine whether the corporate rice farming has or has not been efficient technically, economically, and allocatively. If the $\mathrm{p}$-value is greater than $\alpha$ $5 \%$, or if the t-count is smaller than the t-table, the rice farming is efficient. Conversely, if the $\mathrm{p}$-value is smaller than $\alpha 5 \%$, or the $\mathrm{t}$-count is greater than the t-table, the rice farming is not efficient. The results of the analysis of the average difference test on technical, economic, and allocative efficiency show that the p-value (0.000) is smaller than the $\alpha$ value of $5 \%$ (Table 4 ). This means that the average value of technical efficiency is 0.75 , the economic efficiency is 0.84 , and the allocative efficiency is 1.12 , which are significantly different from the value of one. Thus, the corporate farming of the Sukoharjo Regency is not yet efficient. 
TABLE 4. DIFFERENT TEST FOR AVERAGE TECHNICAL, ECONOMIC AND ALLOCATIVE EFFIIIENCY AGAINST VALUE 1 IN 2018-2019

\begin{tabular}{lllrrrr}
\hline \multicolumn{1}{c}{ Efficiency } & $\boldsymbol{t}$ & Df & \multicolumn{1}{c}{ Sig.(2-tailed) } & \multicolumn{1}{c}{ Mean Difference } & \multicolumn{1}{c}{ Lower } & \multicolumn{1}{l}{ Upper } \\
\hline Technical & -15.894 & 50 & 0.000 & -0.2422 & -0.2728 & -0.2116 \\
Economic & -10.246 & 50 & 0.000 & -0.1613 & -0.1924 & -0.1302 \\
Allocative & 5.145 & 50 & 0.000 & 0.1178 & 0.0718 & 0.1638 \\
\hline
\end{tabular}

Source: Primary Data Analysis

${ }^{* * *}$ : significant at the $1 \%$ level

\section{Technical Inefficiency}

The results of technical efficiency analysis show that, in the model, there is still a technical inefficiency problem in production by $15 \%$. It is suspected that several internal factors are originating from the socio-economic characteristics that are the source of technical inefficiency in the corporate farming model of rice farming. Therefore, in order to find out the source of inefficiency in the corporate farming in Sukoharjo Regency, an analysis of sources of technical inefficiency was conducted. The analysis of sources of technical inefficiency used a frontier stochastic production function model. The results of the analysis of the frontier stochastic production function on the factors that affect the inefficiency of corporate farming show that the variables of education, number of family members, and extension have significantly increased efficiency (Table 5).

The age variable has a negative but not significant effect on inefficiency with an estimated coefficient of -0.0122 which means that the age of the farmer does not have a statistical effect on efficiency. Respondent farmers are heads of farm families who are managers and cultivators of corporate land whose age (73\%) is still relatively young. This proves that the corporate farming model is in great demand by young farmers and tends to produce more efficient farming (Kusnadi, Tinaprilla, Susilowati, \& Purwoto (2011). This result is contrary to the findings of Yoko, Syaukat, \& Fariyanti (2014) and Suharyanto, Mulyo. Darwanto, \& Widodo (2015) stated that age has a significant effect on inefficiency, the older the farmer, the more increasing the level of farming inefficiency.

Education has a significant negative effect on inefficiency with an estimated coefficient of -0.1957 . This means that farmers with higher level of education are more efficient than farmers who have never received formal education. The condition in the field shows that $60 \%$ of farmers' education is low so that it becomes an inefficiency problem, and this is the basis for government policy to improve education and managerial skills of farmers (Kusnadi, Tinaprilla, Susilowati, \& Purwoto, 2011). Farming management through corporate farming becomes non-formal education to increase knowledge and technical skills in farming. It is hoped that farmers with low education will become members of corporate farming, and information is more available and easier to obtain. They are also expected to be open to new technology. Besides, corporate farming can be used as a medium for exchanging experiences so that illiterate farmers can learn from fellow farmers. The negative effect of education on inefficiency is in line with the findings by Kusnadi, Tinaprilla, Susilowati, \& Purwoto (2011) and Suharyanto, Mulyo, Darwanto, \& Widodo (2015), that education has a significant 
negative effect at the $\alpha$ level of 5\% which means the higher the education of rice farming farmers, the more efficient they are.

TABLE 5. RESULTS OF THE STOCHASTIC FRONTIER PRODUCTION FUNCTION AGAINST FACTORS AFFECTING THE TECHNICAL INEFFICIENCY OF RICE FARMING CORPORATE FARMING IN SUKOHARJO REGENCY 2018-2019

\begin{tabular}{|c|c|c|c|c|}
\hline Variable & Expectation Value & Coefficient & Std.Error & t-ratio \\
\hline Constant & $+/-$ & 1.1332 & 0.7642 & 1.4828 \\
\hline Ln age & + & -0.0122 & 0.1869 & -0.0656 \\
\hline Ln education & - & $-0.1957^{* * *}$ & 0.0570 & -3.4304 \\
\hline Ln experience & - & -0.0136 & 0.0609 & -0.2239 \\
\hline In members of family farmer's & - & $-0.1054^{* *}$ & 0.0508 & -2.0714 \\
\hline Ln extension & - & $-0.1251^{*}$ & 0.0709 & -1.7637 \\
\hline (Dummy) membership actively & - & -0.0338 & 0.0708 & -0.4780 \\
\hline
\end{tabular}

Source: Primary Data Analysis

${ }^{* * *}$ : significant at the $1 \%$ level, $\mathrm{t}$-table $1 \%=2.6799$

${ }^{* *}:$ significant at the $5 \%$ level, $\mathrm{t}$-table $5 \%=2.0095$

$*$ : significant at the $10 \%$ level, t-table 10\% $=1.6765$

Experience has no significant effect on inefficiency with a coefficient of -0.0136 . This means that the length of the farming experience does not count towards inefficiency. This shows that rice farming is a hereditary agricultural model that has become a habit without providing agents of change in terms of farming efficiency. The results are contrary to the research by Suharyanto, Mulyo, Darwanto, \& Widodo (2015), that experience has a real effect on efficiency where increased farming experience reduces inefficiency because experience becomes a source of good cultivation knowledge through the fellow farmers' experience.

The number of family members has a significant negative effect on inefficiency with a coefficient value of -0.1054 . This means that if there are more family members in the productive age, the rice farming is technically more efficient. It is in line with the findings of Yoko, Syaukat, \& Fariyanti (2014), where the number of families in the productive age tends to be more efficient than farmers with a few productive family members. Based on the field results, the average number of farmer's family members is 2 to 3 people. Productive family members of corporate rice farming are used for activities that are not carried out collectively, such as weeding, fertilizing, and maintaining. The rest are used outside family labor.

The extension has a significant effect on inefficiency with a negative coefficient of 0.1251 . This figure means that extension is a factor to increase farm efficiency. The higher the frequency of farmers attending counseling, the more information, and knowledge they have in their farm managerial. This is in line with the findings of Prayoga, (2010); Tsoho, Omotesho, Salau, \& Adewumi (2012), and Yoko, Syaukat, \& Fariyanti (2014), that extension variables are negatively related to inefficiency. Based on field conditions, $88 \%$ of farmers actively participate in extension services, while the remaining $12 \%$ have never attended extension services. Farmers who do not participate in the counseling are elderly farmers and those who make the agricultural sector as a side job. The average frequency of farmers participating in extension is 2 times. Most of the counseling was carried out by the Agriculture Office of Sukoharjo Regency, field extension officers (PPL), agricultural extension offices, fisheries and maritime offices, Bank of Indonesia, and the Ministry of Agriculture. Field 
extension officers are the ones who provide the most counseling to farmers of the corporate farming rice, either directly on stretches of land or through farmers group union and farmer groups.

The group activeness dummy has no significant effect with the estimated coefficient of -0.0338 which indicates that whether or not the group members are active does affect inefficiency. The field conditions indicate that corporate farming members are most active in the activities of the invited farmer groups. Representatives of members who actively participate in group activities provide information to fellow corporate farmers. However, the corporate farming model has not been fully accepted. They need corporate membership only for the sake of receiving assistance so they feel they need to become members. This is not in line with the findings of Kusnadi, Tinaprilla, Susilowati, \& Purwoto (2011), that group membership variables have a significant effect on inefficiency, where the participation of farmers in activities will increase inefficiency.

\section{CONCLUSIONS}

The corporate farming model of rice production is significantly influenced by the variable of production factors for land area, urea, and NPK fertilizer, while SP-36 fertilizer, pesticides, and labor do not affect rice production. Of all the variables of production factors for land area, pesticides, and labor, it shows a positive coefficient of estimation, meaning that the use of production factors for land area, pesticides, and labor can increase rice production. Urea, SP-36, and NPK fertilizers show a negative regression coefficient on production, which means that the use of fertilizers can reduce rice production so that the use of fertilizers needs to be reduced.

The analysis of the efficiency of corporate farming in the Sukoharjo Regency is not technically, economically, and allocatively efficient. The average index of technical, economic, and allocative efficiency were $0.75,0.84$, and 1.12 , which differed significantly from the value of one. This means that in order to achieve the highest degree of technical, economic, and allocative efficiency, it is necessary for managerial to reduce or to add production factors. Thus, intensification through corporate farming is still possible through optimizing the use of basic technology. Besides, the need to reduce the operational costs of land processing tools and machines, seeding, planting, and harvesting is still high so that cost-efficiency can be achieved.

All variables that are thought to affect inefficiency show a negative regression coefficient which means that all variables together can reduce inefficiency. Socio-economic factors that significantly reduce inefficiency are education, number of family members, and counseling, while social factors; age, experience, and activity dummy in groups do not have a significant effect on the technical inefficiency of corporate farming. 


\section{REFERENCES}

Akbar, I., Budiraharjo, K., \& Mukson. (2017). Analisis Faktor-Faktor yang Mempengaruhi Produktivitas Padi di Kecamatan Kesesi Kabupaten Pekalongan. Jurnal Agrisocionomics Sosial Ekonomi Pertanian, 1(2), 99-111. https://doi.org/http://ejournal2.undip.ac.id/index.php/agrisocionomics

Apriyantono, A. (2007). Acuan Penetapan Rekomendasi Pupuk N, P, Dan K Pada Lahan Sawah Spesifik Lokasi. Retrieved from http://perundangan.pertanian.go.id/

Asiama, K. O., Bennett, R. M., \& Zevenbergen, J. A. (2017). Land consolidation on Ghana's rural customary lands: Drawing from The Dutch, Lithuanian and Rwandan experiences. Journal of Rural Studies, 56, 87-99. https://doi.org/10.1016/j.jrurstud.2017.09.007

BPS. (2018). Luas Panen, Produksi dan Produktivitas Padi Sawah/Landang (Vol. 0). Retrieved from https://jateng.bps.go.id/

Darwanto. (2010). Analisis Efisiensi Usahatani Padi Di Jawa Tengah (Penerapan Analisis Frontier). Organisasi Dan Manajemen, 6, 46-57.

Defidelwina, Jamhari, Waluyati, L. R., \& Widodo, S. (2019). Dampak Kepemilikan Lahan Padi Sawah Terhadap Efisiensi Teknis dan Efisiensi Lingkungan di Kabupaten Rokan Hulu The. Journal of Agribusiness and Rural Development Research Mengkonsumsi, 5(1), 80-87. Retrieved from http://dx.doi.org/10.18196/agr.5177

Jondrow, J., Lovell, C. A. K., Materov, I. S., \& Schmidt, P. (1982). On The Estimation of Technical Inefficiency In The Stochastic Frontier Production Function Model. Journal of Agricultural Economics, 19, 233-238.

Kostov, P., Davidova, S., \& Bailey, A. (2019). Comparative Efficiency of Family and Corporate Farms: Does Family Labour Matter? Journal of Agricultural Economics, 70(1), 101115. https://doi.org/10.1111/1477-9552.12280

Kusnadi, N., Tinaprilla, N., Susilowati, S. hery, \& Purwoto, A. (2011). Analisis Efisiensi Usahatani Padi Di Beberapa Sentra Produksi Padi Di Indonesia. Jurnal Agro Ekonomi, 29(1), 25-48.

Lerman, Z., \& Sedik, D. (2007). Productivity and Efficiency of Corporate and Individual Farms in Ukraine. 2007 Annual Meeting, July 29-August 1, 2007, Portland, Oregon, (July).

Liu, J., Jin, X., Xu, W., Sun, R., Han, B., Yang, X., ... Zhou, Y. (2019). Influential factors and classification of cultivated land fragmentation, and implications for future land consolidation: A case study of Jiangsu Province in eastern China. Land Use Policy, 88(September), 104185. https://doi.org/10.1016/j.landusepol.2019.104185

Munnangi, A. K., Lohani, B., \& Misra, S. C. (2020). A review of land consolidation in the state of Uttar Pradesh, India: Qualitative approach. Land Use Policy, 90(September 2018), 104309. https://doi.org/10.1016/j.landusepol.2019.104309

Musthofa, I., \& Kurnia, G. (2018). Prospek Penerapan Sistem Corporate Farming (Studi Kasus di Koperasi Pertanian Gerbang Emas). Jurnal AGRISEP, 17(1), 11-22. https://doi.org/10.31186/jagrisep.17.1.11-22 
Prayoga, A. (2010). Produktivitas dan Efisiensi Teknis Usahatani Padi Organik Lahan Sawah. Jurnal Agro Ekonomi, 28(1), 1. https://doi.org/10.21082/jae.v28n1.2010.1-19

Pudaka, D. L., \& Prasetyo, P. E. (2018). Efficency Analysis of Rice Production and Farmers' Income in Sengah Temila District Landak Regency. Journal of Economic Education, 7(1), 31-38. https://doi.org/10.15294/jeec.v7i1.22799

Riyadi, A., Hartono, S., \& Andri, K. B. (2015). Faktor Yang Berpengaruh Terhadap Produksi dan Tingkat Efisiensi Teknis Padi Sawah di Kabupaten Polewali Mandar. Agrise, XV(3), 147-154. Retrieved from agrise.ub.ac.id/index.php/agrise/article/viewFile/173/188

Suharyanto, S., Mulyo, J. H., Darwanto, D. H., \& Widodo, S. (2015). Analisis Produksi dan Efisiensi Pengelolaan Tanaman Terpadu Padi Sawah di Provinsi Bali. Jurnal Penelitian $\begin{array}{llll}\text { Pertanian Tanaman } & \text { Pangan, } & 34(2), & \end{array}$ https://doi.org/10.21082/jpptp.v34n2.2015.p131-143

Susilowati, S. H., \& Maulana, M. (2016). Luas Lahan Usaha Tani dan Kesejateraan Petani: Eksistensi Petani Gurem dan Urgensi Kebijakan Reforma Agraria. Analisis Kebijakan Pertanian, 10(1), 17. https://doi.org/10.21082/akp.v10n1.2012.17-30

Tsoho, B. A., Omotesho, O. A., Salau, S. A., \& Adewumi, M. O. (2012). Determinants of Technical, Allocative and Economic Efficiencies among Dry Season Vegetable Farmers in Sokoto State, Nigeria. Journal of Agricultural Sciences, 3(2), 113-119. https://doi.org/10.1080/09766898.2012.11884692

Yoko, B., Syaukat, Y., \& Fariyanti, A. (2014). Analisis Efisiensi Usahatani Padi di Kabupaten Lampung Tengah. Jurnal Agribisnis Indonesia, 2(2), 127-140.

Yuliana, Y., Ekowati, T., \& Handayani, M. (2017). Efisiensi Alokasi Penggunaan Faktor Produksi pada Usahatani Padi di Kecamatan Wirosari, Kabupaten Grobogan. AGRARIS: Journal of Agribusiness and Rural Development Research, 3(1). https://doi.org/10.18196/agr.3143

Zakaria, A. K., \& Rachman, B. (2013). Implementasi Sosialisasi Insentif Ekonomi dalam Pelaksanaan Program Perlindungan Lahan Pertanian Pangan Berkelanjutan (PLP2B). $\begin{array}{lllll}\text { Forum Penelitian } & \text { Agro }\end{array}$ https://doi.org/10.21082/fae.v31n2.2013.137-149 